\title{
Christian invocations in the papyri (*)
}

I

a remarkable paper delivered to the Fifteenth International Congress of Papyrology and subsequently published ('), Zbigniew

Borkowski has undertaken to examine the date and the significance of the introduction of the invocation formula into papyrus documents of the late sixth and early seventh century, following up the perceptive but avowedly preliminary remarks by H. I. BELl in Byz. Zeitschr. 22 (1913) 400. Among his conclusions which seem firmly established are the following :

1) The invocation, like regnal dating of documents, was instituted by imperial decree, in this case of Mauricius.

2) Whatever the date of this decree (John of Nikiou $\left({ }^{2}\right)$ places it at the outset of the reign), its force is felt in Egypt first in the year 591.

3) Under Phocas a trinitarian formula replaced the Christ formula found under Mauricius, although a few of the old form turn up in Upper Egypt.

4) In Lower Egypt and Arcadia the formula used under Mauricius was restored under Heraclius, while in Upper Egypt the trinitarian formula continued in use.

(*) As usual we are very much indebted to several friends for their help, checking readings, providing photographs, supplying bibliographical references, reading our rough drafts : Zbigniew Borkowski, Gerald M. Browne, J. D. Diethart, I. F. Fikhman, Hermann Harrauer, Leslie S. B. MacCoull, P. J. Parsons, T. S. Pattie, G. Poethke and J. Schwartz.

(1) Zbigniew Bofkowskr, Inscriptions des factions à Alexandrie (Centre d'Archéologie Mediterranéenne de l'Académie Polonaise de Sciences et Centre Polonais d'Archéologie Méditerranéenne dans la République Arabe d'Égypte au Caire, sous la direction de K. Michalowski : Alexandrie II, Warszawa, in the press). We are grateful to Dr. Borkowski for providing us with a copy of the manuscript of this chapter well before its publication. We note here abbreviations other than the usual in this article: P. Cair. Arab. III = A. Grohmax, Arabic Papyri in the Egyptian Library III (Cairo 1938); CSBE = R. S. BAGNALL and K. A. Worp, Chronological Systems of Byzantine Egypt (Stud. Amst. 8, Zutphen 1978); RFBE = Idem, Regnal Formulas in Byzantine Egypt (BASP Suppl. 2, Missoula 1979); CNBD = Idem, \& Chronological Notes on Byzantine Documents, " in BASP 15 (1978) and following, cited by installment and item number in cases where they are unpublished at the time of writing.

(2) Chronique, ch. 99 (Bibliothèque Nationale, Notices et Extraits, t. 24). 
5) The end of Mauricius' reign and the start of Phocas', and again the end of Phocas' reign with the revolt of Heraclius, were - like the Persian occupation and the Arab conquest - periods when the disturbance of imperial rule led to the absence of regnal formulas. A number of documents can be dated definitively to the period 598-610.

Borkowski does not, however, give a list of documents with invocations, nor classify them by provenance. The results of the collection which we have made for our own use seem interesting enough to warrant publishing them for the use of others, and we find in the process that some refinements may be made which can have practical use to the student of this period. We have limited ourselves to documentary papyri (1), but we have inconsistently included a few Greek inscriptions from Egypt $\left({ }^{2}\right)$. We do not claim that our collection of invocations from Coptic sources is complete.

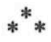

\section{Invocations attested in the papyri}

1. Christ

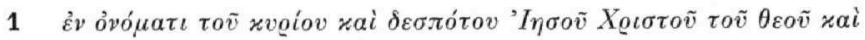
$\sigma \omega \tau \tilde{\eta} \varrho \circ \varsigma \dot{\eta} \mu \tilde{\omega} \nu$

(1) We cannot enter into the question of Mauricius' reasons for introducing the invocation as a required part of legal acts. On his piety, ef. B. BALDwIN, * Menander Protector s, DOP 32 (1978), 102-103, 113 ; Menander was at least concerned to present him as especially pious. The use of invocations in liturgical contexts, inscriptions and legal texts (cf. $C J$, introduction) is much older and an entirely different matter, into which we do not go.

(2) We do not include Greek renderings of the Arabic Bismillah, which are common e.g. in the Apollonos Ano papyri ; cf. P. Apoll. 4.1n. and CPR III.1 86, III.2 xxvii ff. Our formula $2 I$ has been influenced by the Bismillah. Furthermore we encounter

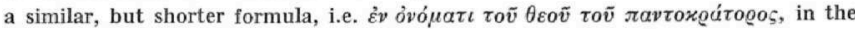
following papyri :

Antaiopolite

Jeme (Thebes)
712

post $747 / 8$

$767 / 782$

775

776
P. Soc. Omaggio 14

KRU 90, Till (cf. below, p. 123, n. 2), 34 ; in Coptic

KRU 118 ; Till 41

KRU 96 ( $S B$ I 5605) ; Till, 36

KRU 80 ( $S B$ I 5593); Till, 29; adds $\pi \alpha \tau \varrho o ́ \varsigma$ after $\theta \varepsilon o \tilde{v}$ 
2. The Holy Trinity

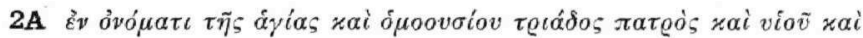

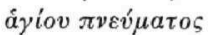

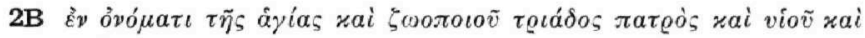
å $\gamma$ íov $\pi v \varepsilon v ́ \mu \alpha \tau o \varsigma$

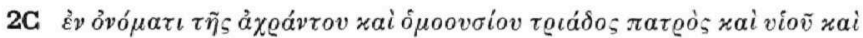

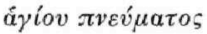

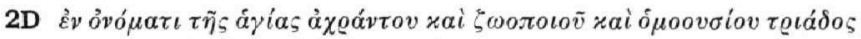

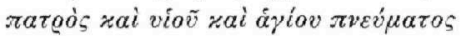

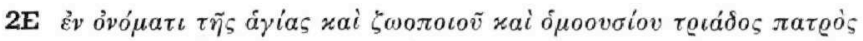

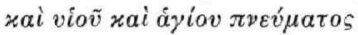

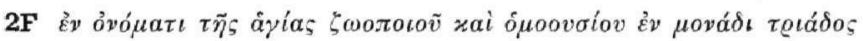

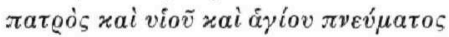

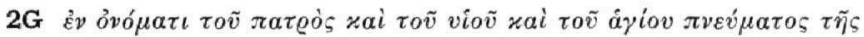

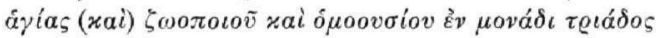

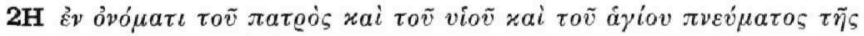

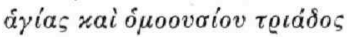

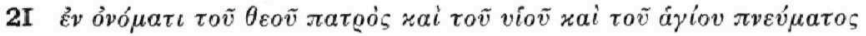

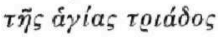

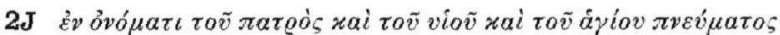

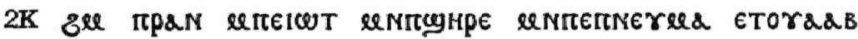

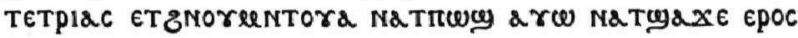

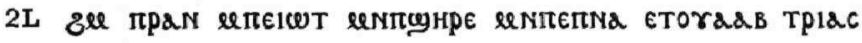
NGOeeOOrCION

For another possible variant Coptic formula cf. CPR IV $180.1 \mathrm{n}$.

\section{The Holy Trinity, Mary (and Saints)}

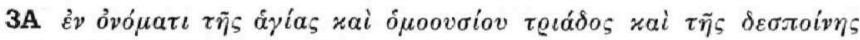

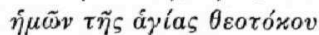

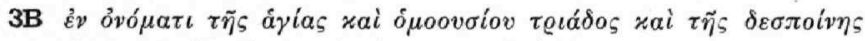

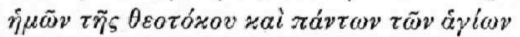




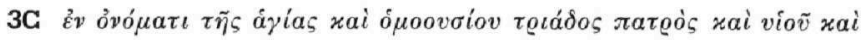

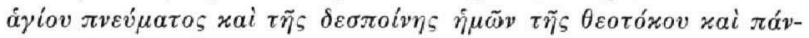
$\tau \omega \nu \tau \tilde{\omega} \nu \dot{\alpha} \gamma i \omega v$

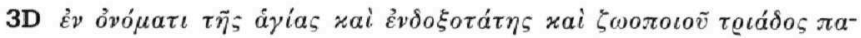

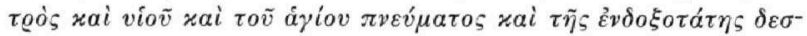

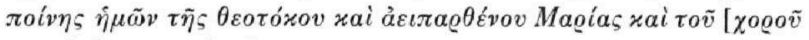

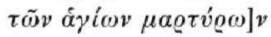

\section{Christ, Mary and Saints}

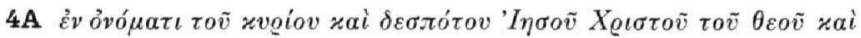

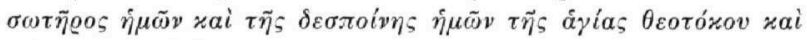
$\tau a ́ v \tau \omega v \tau \tilde{\omega} v \hat{\alpha} \gamma i \omega v$

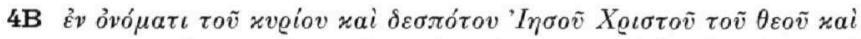

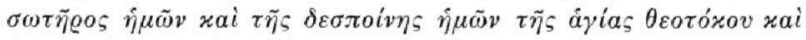

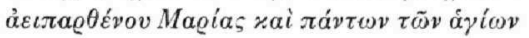

\section{Attestations by period and formula}

\section{Mauricius}

The first instance of an invocation in Lower Egyptian papyri comes in P. Erlangen 67, a Herakleopolite text of 17. ix. 591 ; the first Upper Egyptian example of an invocatio is P. Stras. 190 of 27. vii. 592. Earlier texts from both Lower and Upper Egypt, as far as completely preserved, still lack the invocatio. In view of the relatively short lapse of time between 17. ix. 591 and 27. vii. 592 we consider it reasonable to assume that the date of the introduction of the invocation as an element of document headings fell simultaneously in Lower and Upper Egypt somewhere not too long before 17. ix. 591 (P. Oxy. XVI 1990 of 12 . i. 591 still lacks this element : for $S B$ I 4858 , erroneously dated to 2 . vi. 591 by the editor, cf. $Z P E 45$ (forthcoming)). The invocation is thenceforth usual in legal documents of Mauricius' reign. The form is always 1 ; no other form is found in this reign, and except as noted below, all known legal documents of this reign dated after September 591 have this invocation. The list in RFBE 58-64 contains all of these documents then known to us classified by regnal formula and provenance ; add now $P$. Köln III 158. 1 (Herakleopolite, 16. x. 599) ; SB I 5321 (Arsinoite, 591-602) ; P. Lond. 
III 1304a descr. (Hermopolite, 592/3, cf. CNBD VII 70) ; SB VI 9586 (Hermopolite, 12. xii. 600) ; P. Wash. Univ. 26. 1 (Oxyrhynchite, 1. x. 596) ; and presumably P. Vatic. Aphrod. 1.1 (Antaiopolite, 23. ix. 598; editor wrong that Trinity is possible).

The following documents dated after 17. ix. 591 apparently lack an invocation, to judge from the edition :

\begin{tabular}{|c|c|c|c|}
\hline P. Paris 21 bis & 592 & Thinite & complete at top \\
\hline P. Oxy. XVIII 2202 & 593 & Oxy. & top probably lost \\
\hline P. Lond. V 1898 & $594 / 5(?)$ & Hermop. & complete \\
\hline $\begin{array}{l}\text { P. Lond. III } 1005 \\
=S B \text { VIII } 9932\end{array}$ & $598 / 9(?)$ & Hermop. & $C N B D \quad$ II \\
\hline
\end{tabular}

It should be pointed out that some element of doubt exists about the date in two of these : P. Lond. V 1898 and SB VIII 9932. Considering the strong probability that P. Oxy. XVIII 2202 is incomplete at the top $\left({ }^{2}\right)$, one might well be tempted to argue that the uncertain dates were probably incorrect, which would leave only one secure exception, that from 592, right after the introduction of the invocation. In the case of $S B$ VIII 9932 a date under Justinian may well be possible; but $P$. Lond. V 1898 cannot, we think, be earlier than 594/5. We are therefore not persuaded that a wholesale elimination of exceptions is possible. Nonetheless, there are not very many exceptions, and the burden of proof rests on whoever would date after 591 a document lacking an invocation.

Another exception might appear to be found in P. Stras. 318, a Herakleopolite document for which we argued for a date of 19. ix. 594 in BASP 16 (1979), 239-40, and which in its publication shows no sign of an invocation. But Professor J. Schwartz informs us that a newly found fragment shows that the previous line 1 is really line 2 ; that the new line 1 contains a standard Christ invocation ending with $\tilde{\eta} \mu \tilde{\omega} v$ in line 2 , which is thus four letters longer than expected; and that this additional space is in turn long enough to allow $\pi \varepsilon v \tau \varepsilon \kappa \alpha l^{-}$ $\delta \varepsilon x \alpha \dot{\tau} \eta \xi$, which he reads in line 5 (old 4), where we had argued that $\tau \varrho \iota \sigma x \alpha \iota \delta \varepsilon x a ́ \tau \eta \varsubsetneqq$ would fit the space best. The date is thus 19 .ix. 596 ; our restoration of Thoth, which was the critical point for the argument

(1) BASP 16 (1979), 230-31. We assert there the correctness of the editor's date of $598 / 9$. We still think this is possible, but the presence of this text in a list of exceptions might give some credence to a restoration of Justinian formula 2 (RFBE 46) plus the p.c. of Fl. Basilius, in which case the date would be 4. i. 544 .

(2) We thank Peter Parsons for examining this papyrus for us, 
about the indiction in the Herakleopolite Nome, is confirmed by the new fragment. At all events, this piece does have an invocation.

In the following cases the tops are definitely missing and the lack of an invocation is therefore the result of damage :
P. Amh. II 150
592
Oxyrhynchite
P. Oxy. XXVII 2478
595
Oxyrhynchite
P. Ross. Georg. V 42
$602(?)$
Hermopolite ${ }^{1}$ )

$P$. Lond. III 1315a, finally, may be either 585 or 600 (by the indiction). Its top is complete, and it lacks the invocation. There is a chance that it is thus also a late example of no invocation, but more probably one may consider that the absence of an invocation points to 585 as the true date.

A number of papyri have been edited with forms of this Christ invocation which do not conform to the standard phrasing in all details. Most of these are erroneous readings or restorations by editors :

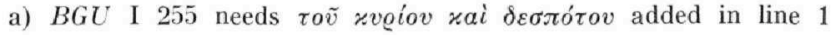

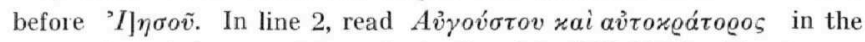
restoration of the regnal formula (so listed in $R F B E 59$ without com-

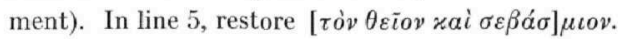

b) $B G U$ I 309 : the initial restoration is too short, and an additional line is needed before the present line 1 . We propose the following:

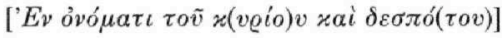

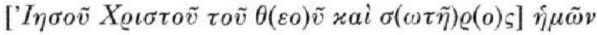

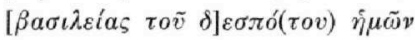

c) $B G U$ II 402 omits $\tau o \tilde{v}$ before xveiov according to the editor's reading; Dr. G. Poethke tells us that this is correct.

d) P. Alex. $33:$ In place of the editor's restoration of the start of the

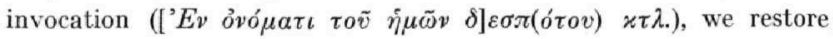

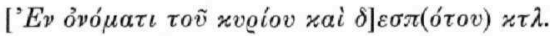

e) $S B$ I 4801 adds a superfluous $\hat{\eta} \mu \tilde{\omega} \nu$ in the restoration (by Preisigke) after $\delta \varepsilon \sigma \pi o ́ \tau o v$. This should be deleted.

f) $S B$ I 4858 has $\dot{\eta} \mu \tilde{\omega} v$ after $\left.\delta \varepsilon \sigma \pi \kappa^{\prime} \tau v: \dot{\eta} \mu\right] \tilde{\omega} v$, but this is an editorial error. For a re-edition of the text cf. ZPE 45, forthcoming.

(1) We thank Dr. I. F. Fikhman for supplying us with a photo of this papyrus from which we see that the top of the papyrus is incomplete. 
g) $S B$ VI 9153 : the editor restores $\dot{\eta} \mu \tilde{\omega} \nu$ where $\alpha a i \quad \delta \varepsilon \sigma \pi(o ́ \tau o v)$ (abbreviated or in full) are needed; the correct form is to be restored instead.

Finally, one non-Egyptian example deserves comment. P. Ness. 30 has a regular formula except for two irregularities introduced by the editor, who reads $\dot{\eta}[\mu \tilde{\omega} v$ before $\delta] \varepsilon \sigma \pi o ́ \tau o v$; read instead $\chi[\alpha i \delta] \varepsilon \sigma \pi o^{-}$ $\tau o v$. And in place of the editor's $v[i a \tilde{v}] \theta \varepsilon o \tilde{v} \operatorname{read} \tau[o \tilde{v}] \theta \varepsilon o \tilde{v}$.

We note that $S B$ I 4812 may belong to this reign (for the regnal formula cf. $R F B E 62$, form. 8) or to that of Heraclius (cf. $R F B E 69$, form. 2).

\section{Phocas}

Formula 1 is found in five documents of Phocas' reign. These are :

$\begin{array}{lll}P . \text { Laur. III 77 } & 603 & \begin{array}{l}\text { Hermopolite ; for the date } \\ \text { see BASP 18 (1981) } 46\end{array} \\ \text { SB I } 4503 & 605 \text { or } 607 & \text { Thinite } \\ \text { SB I } 4505 & 606 \text { or } 608 & \text { Thinite } \\ \text { CPR IV 23 } & 608 & \text { Panopolite } \\ \text { SB I } 4876 & 602-610 & \text { ? }\end{array}$

All of these are Upper Egyptian except perhaps $S B$ I 4876, which came to the Louvre as part of the Fayum find. As we have pointed out, however ( ${ }^{1}$ ), this provenance is not a reliable guide. Except for Phocas' name, all indication of the date of $S B 4876$ is lost.

Aside from the four documents mentioned above, all papyri of Phocas' reign with invocations invoke the Holy Trinity. (The top of $P$. Lond. III 871 [p. 269 ; Arsinoite, 603] is lost.) A number of forms are found, which will be set out by formula and provenance.

\section{The Holy Trinity}

2A Hermopolite 602

2B Hermopolite

2? Hermopolite 604/5

2G Unknown $\quad 606$ (Oxyrhyn- 609 chite?)

2E Oxyrhynchite 609

2J Panopolite 607

$607 \quad S B$ I 5286

PSI I 61

$S B$ I 5285
$S B$ VI 9403 (cf. $Z P E 35$ [1979] 140 ; ed. princ. wrong that invocation was completely lost) $B G U$ XII 2207

P. Ross. Georg. III 49 (only end preserved; cf. ed.'s note line 1 where formula $\mathbf{2 J}$ proposed P. Laur. III 91 (cf. below, p. 129) $S B$ XII 10798 (see BASP 17 [1980] 111)

(1) See BASP 16 (1979), 243 n. 4. 
3. The Holy Trinity, Mary, (and Saints)

\begin{tabular}{|c|c|c|c|}
\hline 3A & Arsinoite & 603 & $B G U$ II 365 \\
\hline & & 608 & 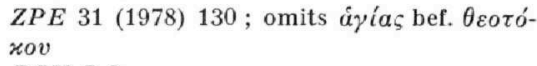 \\
\hline 3B & Arsinoite & 605 & $B G U$ I 3 \\
\hline & & 606 & $S B$ I 4838 \\
\hline & & 606 & $\begin{array}{l}\text { P. Vindob. Tandem } 32 \text { (cf. } Z P E \\
132 \mathrm{n} .2 \text { ) }\end{array}$ \\
\hline $3 \mathbf{C}$ & Arsinoite & 604 & $S P P \times \times 219$ \\
\hline & & $604 / 5\left(^{1}\right)$ & $S B$ I 4836 \\
\hline & & 608 & $S B$ I 5266 \\
\hline & & 610 & $\begin{array}{l}S P P \times X 209=S B \text { I } 5270 \text { (date by Bor- } \\
\text { kowski }\left({ }^{2}\right) \text { ) }\end{array}$ \\
\hline & & ? & $S B$ I 4740 (our restoration of end) \\
\hline & & $?\left({ }^{3}\right)$ & $S B$ I 5260 \\
\hline & Herakleopolite & 604 & P. Erl. 73 \\
\hline 3B & or $3 \mathrm{C}$ & & \\
\hline & Arsinoite & 605 & $S B$ I 4748 \\
\hline & & 609 & 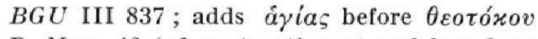 \\
\hline 3D & Palestine & 605 & $\begin{array}{l}\text { P. Ness. } 46 \text { (ed. restoration at end based on } \\
P \text {. Ness. } 89.45 \text {, but } \pi \alpha ́ v \tau \omega v \tau \tilde{\omega} v \hat{\alpha} \gamma \dot{c} \omega] \nu \text { not } \\
\text { excluded) }\end{array}$ \\
\hline
\end{tabular}

Formulas invoking the Holy Trinity come from every part of Egypt, but in those from Upper Egypt and the Oxyrhynchite the Trinity stands alone, while in the Alsinoite and (one) Herakleopolite documents the scribes add Mary or Mary and the Saints. This is a striking regional variation ( $\left.{ }^{4}\right)$.

(1) This text, as an Arsinoite document with a Trinitarian invocation, must belong to Phocas' reign. The 8 th indiction mentioned must therefore be $604 / 5$. The formula to be restored is Phocas form. 3 or 4 ( $R F B E$ 66, where it should be added).

(2) See supra, p. $112 \mathrm{n}$. 1. The regnal formula is omitted.

(3) Restore in line $3: x a i \tau \tilde{\eta} \varsigma \delta[\varepsilon \sigma \pi \circ i ́ v \eta \varsigma \tilde{\eta} \mu \tilde{\omega} \nu \tau \tilde{\eta} \varsigma \theta \varepsilon o \tau o ́ x o v]$. The reading has been verified for us by Dr. H. Harrauer.

(4) Borkowskr (p. 112 n. 1) notices that the Lower Egyptian documents have the Trinity, Mary and Saints formula, but he does not observe that in the Upper Egyptian nomes the trinitarian formula, when it arrives, does so in a different form. Cf. for the cult of Mary, Gabriele Gramberardini, $I l$ culto mariano in Egitto II : Sec. VII-X (Studium Biblicum Franciscanum, Analecta 7, Jerusalem 1974) 159-62 et passim. We are not aware of any study which points to the peculiar local intensity of devotion to Mary which might be inferred from the limitation of her invocation to documents from this region. 


\section{Heraclius}

Under Heraclius a major division takes place, in which the Upper Egyptian nomes use the Trinitarian formula introduced under Phocas (or a variation thereof: this is the formula with by far the most Iocal variants), while the Lower Egyptian nomes revert to the formula of Christ in use under Mauricius. Our attestations are classified accordingly.

\section{Upper Egypt}

\section{$2 \mathrm{~A}$ or $2 \mathrm{~B}$}

Thinite

2B Hermopolite

$S B$ I 4504 ; editor restores ópoovoíov,

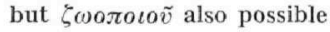

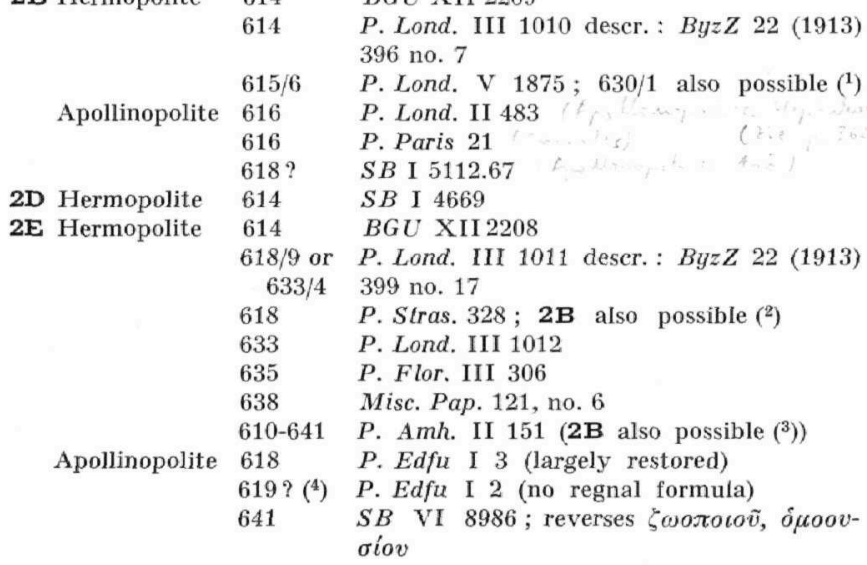

(1) P. Lond. V 1874 may be Phocas, regnal formula 5, or Heraclius, regnal formula 6 ; it is regnal year 3, but the Emperor's name is lost. If Phocas (as we think more likely), the date is 605 , and it should be added to $R F B E$ in the proper place. $B G U$ XII 2210 (617) begins like 2B, but it seems to have insufficient space for it, cf. editor's note to line 1. SB I 4812 may be either Mauricius or Heraclius (cf. supra, p. 118).

(2) Editor restores as 2A, áriov zai ónoovoíov, which is otherwise not attested under Heraclius.

(3) Cf. n. 13.

(4) The date poses problems. P. Edfu 2 has only month and indiction, but the editor dated it to ii-iii. 619. Wilcken remarked (Archiv 13 [1939] 150-51) that the omission of the regnal formula pointed to the absence of Byzantine rule, hence the 


\section{Lower Egypt}

All documents from the Lower Egyptian nomes (Oxyrhynchite, Arsinoite, Herakleopolite) from Heraclius' reign in which the start of the text is preserved have the Christ formula 1. The sole exception is P. Lond. I 113 (6.a) (p. 212), an Arsinoite papyrus to be dated to 2. iv. 612, early in Heraclius' reign, in which formula 3C, one of the Arsinoite trinitarian formulas of Phocas' reign, is still used (with the addition of

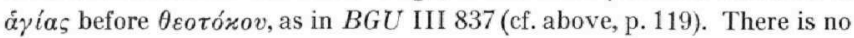
regnal formula ; but the invocation is impossible either under Mauricius (597) or later in Heraclius' reign, and no 15th indiction falls in Phocas' reign. Perhaps the Arsinoite was still somewhat disturbed at this point. in Heraclius' reign ; there is no document with a regnal formula from the Arsinoite until 615 ( $B G U$ II 368). We do not accept the date to A.D. 627 as proposed by H. I. Bell (cf. BL I 238).

The tops of the following documents are lost : P. Oxy. I 139 ; P. Lond. I 113 (10) (p. 222) ; SB I 4319, 4497, 4746, 5112,-5114, and 5318; ZPE 19 (1975), 292 and 293 ; P. Lond. V 1736, 1737.

SB I 5271 as presented by the editor appears to conflict with the generalization above. Wessely's text, with Bell's restorations, has formula $\mathbf{3 G}$ in this document of 615 . But on a photograph kindly provided by our Vienna colleagues of this papyrus (P. Vindob. G. 24150), we read and restore the following:

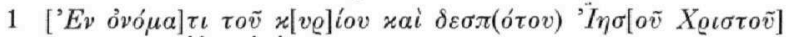

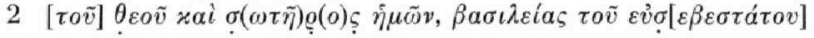
The text thus follows formula 1 as one would expect ${ }^{(1)}$.

\section{DATED DOCUMENTS FROM AFTER THE ARAB CONQUEST}

For the purposes of this section, we include documents in which a date at least as precise as a quarter-century can be found, counting those in

Persian occupation. On the other hand, P. Iand. III 49 (Oxyrhynchite), of 5. vii. 619, does have a regnal formula. The conclusion to be drawn, if the date of $P$. Edfa 2 is indeed 619 , is that regnal formulas were sometimes omitted under Heraclius. Cf. infra, pp. 128, 130 .

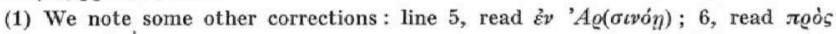

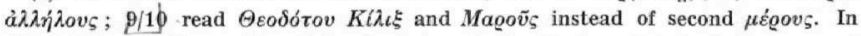
$S B$ I 4488.1 (635), for Wessely's $x[v \varrho i ́ o v]$ read $\theta[\varepsilon o \tilde{]}$, according to J. Gascou, and

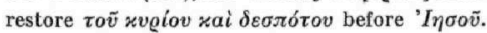


which prosopography is the basis for the date. Many of these have more exact indications of date, but some do not. SB VI 8987 is lacking its invocation.

\section{Upper Egypt}

2E Apollinopolite 647 (ed). SB VI 8988 ; reverses $\zeta \omega o \pi \circ \circ \tilde{v}$, ó $\mu \circ o v$ $\begin{aligned} \text { Jeme (Thebes) } 698 & \text { CLT } 1 \text {; om. second } x a i ́ \\ 722 & \text { KRU } 10 \text { (S B I 5123) ; }\end{aligned}$

$722 / 3 \quad$ KRU 47 (SB I 5580 omits invocation); Till, 24 ; editor misrestores

723 KRU 68 (SB I 5590); Till, 27

724 KRU 36 ( $S B$ I 5572); Till, 23

724 KRU 50 ( $S B$ I 5582); Till, 25

$725 \quad$ KRU 45 ( $S B$ I 5578); Till, 24

ca 730 KRU 27 (SB I 5570); Till, 21

733 KRU 12 (SB I 5561); Till, 19

733 KRU 13 (SB I 5562); Till, 19

733/748 KRU 5 (SB I 5558); Till, 17

733/748 KRU 74; Till, 28 ; mostly lost

$734 \quad$ KRU 88 (SB I 5599); Till, 33

734 KRU 106 (SB I 5609); Till, 39, dates to 735 , but cf. $C S B E 57$, n. 13

747 KRU 19 (SB I 5566); Till, 20

748/763 KRU 54 (SB I 5585); Till, 25

749 KRU 41 ( $S B$ I 5576) ; Till, 23

749 KRU 2 (SB I 5556); Till, 17

$749 \quad$ KRU 4 (SB I 5557); Till, 17

$750 \quad$ KRU 1 ( $S B$ I 5555); Till, 17

$750 \quad$ KRU 70 (SB I 5591); Till, 27

753 KRU 11 (SB I 5560); Till, 19

$756 \quad$ KRU 14 (SB I 5563); Till, 19

756 KRU 15 (SB I 5564)

$758 \quad$ KRU 6 (SB I 5559); Till, 17

post 760 KRU 22 (CPR IV 26); Till, 20

762 KRU 102 ; Till, 38 ; could be $2 \mathrm{~J}$

$763 \quad$ KRU 24 (SB I 5567); Till, 21

$765 \quad$ KRU 71 (SB I 5592); Till, 27

post 765 KRU 58 (SB I 5586); Till, 26

$766 \quad$ KRU 86 ( $S B$ I 5597); Till, 31

post 779 KRU 100 (SB I 5607); Till, 36-38

$780 \quad$ KRU 99 ( $S B$ I 5606); Till, 36

2F Hermopolite $743 \quad$ P. Stras. 397; cf. BASP 15 (1978) 240-44

(1) All references in thís form are to pages of the work cited infra, p. 123, n. 2. Most, but not all, of the Greek invocations in Coptic texts in KRU are extracted in $S B$ I. We give the numbers in parentheses. 


\begin{tabular}{|c|c|c|c|}
\hline \multirow{17}{*}{\multicolumn{2}{|c|}{$\begin{array}{c}2 \mathrm{G} \text { Antaiopolite } \\
\text { (all from } \\
\text { Aphrodito) }\end{array}$}} & 708 & P. Lond. IV 1496 \\
\hline & & 708 & P. Lond. IV 1584 \\
\hline & & 708 & P. Lond. IV 1608 \\
\hline & & 709 & P. Lond. IV 1494 \\
\hline & & 709 & P. Lond. IV 1499 \\
\hline & & 709 & P. Lond. IV 1512 \\
\hline & & 709 & P. Lond. IV 1521 \\
\hline & & 709 & P. Lond. IV 1523 \\
\hline & & 709 & P. Lond. IV 1610 \\
\hline & & 709 & P. Lond. IV 1612 \\
\hline & & ca $708-9$ & P. Lond. IV 1508 \\
\hline & & 710 & P. Lond. IV 1542 \\
\hline & & 711 & P. Lond. IV 1574 \\
\hline & & post 708 & P. Lond. IV 1577 \\
\hline & & $1 / 4$ VIII & P. Cair. Arab. III 164 \\
\hline & & $1 / 4$ VIII & P. Cair. Arab. III 165 \\
\hline & & $1 / 4$ VIII & P. Cair. Arab. III 166 \\
\hline \multirow[t]{16}{*}{$2 J$} & Nubia & 710 & $\begin{array}{l}S B \text { I } 1594 \text { : inscr. from Taifis ; adds } \theta \varepsilon o \tilde{v} \\
\text { before } \pi \alpha \tau \varrho o ́ s \text { (cf. supra, p. } 113 \text {, n. } 2 \text { ) }\end{array}$ \\
\hline & Jeme $\left({ }^{1}\right)$ & $702\left({ }^{2}\right)$ & CLT 4 \\
\hline & (Thebes) & 703 & CLT 2 (in Coptic) \\
\hline & & $724 / 739$ & CLT 6 ; cf. Till, 44 \\
\hline & & $\begin{array}{c}725 / 6 \text { or } \\
740 / 1\end{array}$ & KRU 64 ( $S B$ I 5588) ; cf. Till, 26 \\
\hline & & $725-740$ & CLT 7 ; cf. Till, 44 ; form not certain \\
\hline & & 730 's & $\begin{array}{l}\text { KRU } 7 \text {; cf. Till, } 18 \text {; most likely restoration } \\
\text { (G. M. Browne) }\end{array}$ \\
\hline & & 730 's & KRU 56 ; cf. Till, 25 ; in Coptic \\
\hline & & 738 & VC 6 ; Till, 47 ; in Coptic \\
\hline & & $729 / 744$ & KRU 69 ; Till, 27 \\
\hline & & $740 / 755$ & CLT 10 ; in Coptic \\
\hline & & 770 & KRU 84 (SB I 5596) ; Till, 30 \\
\hline & & 771 & KRU 81 ( $S B$ I 5594); Till, 30 \\
\hline & & 771 & KRU 109 ; Till, 39 (2E also possible) \\
\hline & & post 771 & KRU 82 ; Till, 30 \\
\hline & & 781 & KRU 91 ( $S B$ I 5602) ; Till, 35 \\
\hline \multicolumn{2}{|c|}{$\begin{array}{l}\mathbf{2 K}\left({ }^{3}\right) \\
\text { (Thebes) }\end{array}$} & $698 / 728$ & VC $8 ;$ Till, 47 \\
\hline
\end{tabular}

(1) Coptic texts are cited without comment in cases where the invocation formula is given in Greek. Where the notation * in Coptic , appears, the formula is actually translated into Coptic. These formulas are not quoted here, except for those which are found only in Coptic and which are quoted in full above.

(2) See W. Tru, Datierung und Prosopographie der koptischen Urkunden aus Theben (SitzbWien 240. 1, Wien 1962) 42, for the date. Editor: 672 or 687.

(3) In the name of the Father, Son and Holy Ghost, Trinity in Unity, indivisible and ineffable. 
2L (1) Jeme (Thebes)
719

725

738

759
KRU 35 ; ends ETXHK EBOR a

पTaN8O, "complete and vivifying " KRU 21

KRU 38

KRU 20 ; Till, 20

\section{Lower Egypt}

All attestations are Arsinoite or Herakleopolite.

1

$4 \mathrm{~A}$

$4 \mathrm{~B}$

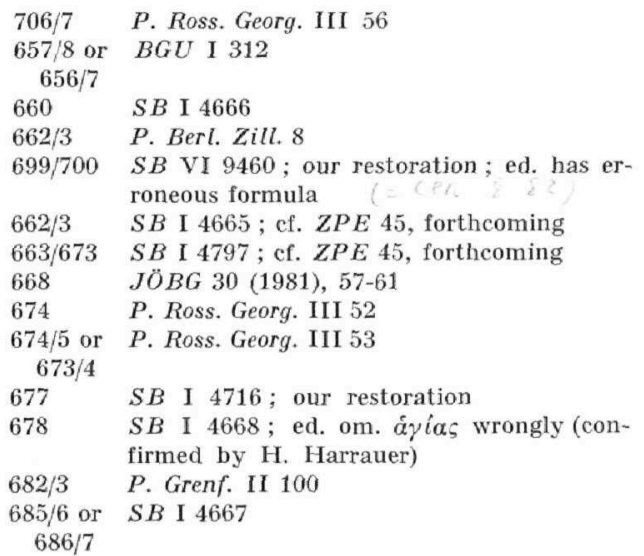

Documents not absolutely datable

(1/2 VIII means first half of the eight century; see Till, 12).

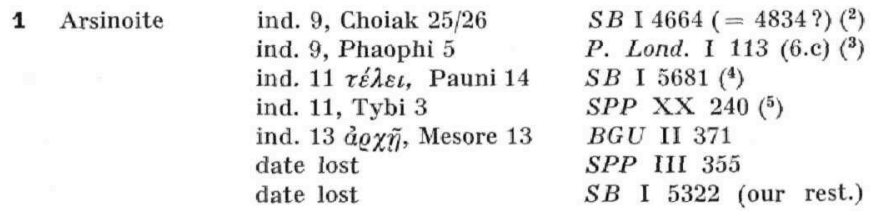

(1) e In the name of the Father, Son and Holy Ghost, the Holy consubstantial Trinity. "

12) Omits $\dot{\eta} \mu \tilde{\omega} \nu$.

(3) Mostly restored.

(4) Cf. $G S B E 61$ n. 52 and $B L$ II.2 120.

(5) Dated to 622 by J. GAscov, BIFAO $76(1976), 147$, n. 7. 
Oxyrhynchite

Hermopolite

\section{B Jeme (Thebes)}

2D Hermopolite

Antaiopolite

Apollinopolite

2E Apollinopolite 2 G Antaiopolite

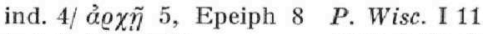

ind. 6 , Thoth 20

PSI I 52 (617? cf. P.

Oxy. XVI, p. 239 ; Bas-

tianini, Mise. Pap. 26)

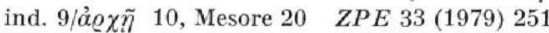

ind. 12, Pauni 28

ind. 13, Phaophi 29

PSI VIII 894

PSI I 63

date lost

date lost (Pachon 19)

$2 / 2$ VIII

ind. 2, Mesore 18

ind. 3, Thoth 21

ind. 7 , Pauni 5

ind. 10, Phaophi 13

ind. 10, Hathyr 14

ind. 10, Phamenoth 7

ind. 11 ảex, Pauni 1

ind. 13, Epag. 5

ind. 13, Phaophi 1

ind. 15

VII/VIII

ind. 4, Hathyr 3

ind. 1 ả $\varrho \tilde{\eta}$, Epeiph

ind. 8, Phaophi 27 ; VII

ind. 8, Phaophi 7

Early VIII ; date lost

Early VIII ; date lost

Early VIII ; date lost

Early VIII ; date lost

Early VIII ; date lost

Early VIII ; date lost

Early VIII ; date lost
ZPE 16 (1975) 65

CPR IV 112 (d) (ed. :

VIII)

ST 97 ; Till, 46

$S B$ VI 9085 , inv. 16166

(ed. : 643)

Archiv 3 (1906) 421.99, $422.122\left({ }^{1}\right)$

P. Flor. I 38 (ed.

$S B$ VI 9591

P. Herm. 34

P. Würzb. $19\left(^{2}\right)$

P. Stras. 310 (ed.

wrongly : VI)

SPP XX 218

P. Stras. $600 \quad\left({ }^{3}\right)$

BKU III 355

Ryl 115 ; formula

uncert.

P. Mich. XIII $662\left({ }^{4}\right)$

P. Edfu I $4\left(^{5}\right)$

ZÄS 60 (1925) 106

Herm 26 (date 4.x.709?)

Herm 36

$P$. Lond. IV 1540

P. Lond. IV 1545

P. Lond. IV 1565

P. Lond. IV 1569

P. Lond. IV 1592

P. Lond. IV 1613 wrongly : VI)

(1) Ed. VIp wrongly (this type of invocation occurs only in the vith century). In place of $X(\varrho) t(\sigma \tau) o(\tilde{v})$ (twice), read viou (confirmed on original by J. Schwartz. For this text ef. also H. Harrauer, Misc. Pap., 125.

(2) Cf. P. Laur. III 77. 3-4n. : 622.

(3) Ed. : $c a 600$.

(4) See $C d^{\prime} E 52$ (1977) $363: 615$ suggested as date.

(5) Cf. CSBE 58 n. 26 ; BL III 47 dates to 627. 


\begin{tabular}{|c|c|c|c|}
\hline & Hermopolite & $841 / 2$ & $\begin{array}{l}\text { BM Or. } 6204 \text { (cf. BM, } \\
\text { Pl. } 5 \text {; ed. } 843 \text { ) }\end{array}$ \\
\hline $2 \mathrm{H}$ & I Hermopolite & ind. 1 , Choiak 1 & $\begin{array}{l}\text { P. Flor. I } 70 \text {; H. Har- } \\
\text { rauer, Misc. Pap. } 124 \text {, } \\
\text { sugg. } 627\end{array}$ \\
\hline $2 I$ & Balaizah & VII/VIII & Bal 152 \\
\hline \multirow[t]{14}{*}{$2 J$} & Jeme (Thebes) & VIII ; ind. 1 & KRU 57 \\
\hline & & ind. 9 , Thoth 9 & ST 59 \\
\hline & & $1 / 2$ VIII & $\begin{array}{l}\text { KRU 16; Till, } 19 \text {; } \\
\text { Coptic }\end{array}$ \\
\hline & & $\begin{array}{l}2 / 3 \text { VIII ; ind. } 1 \text {, } \\
\text { Mesore } 16\end{array}$ & $\begin{array}{l}\text { KRU } 59\left(\begin{array}{lll}S B & \text { I } & 5587\end{array}\right) \text {; } \\
\text { Till, } 26\end{array}$ \\
\hline & & mid VIII & $\begin{array}{l}\text { KRU } 61 \text {; Till, } 66 \text {; } \\
\text { Coptic }\end{array}$ \\
\hline & & mid VIII & $\begin{array}{l}\text { KRU } 62 ; \text { Till, } 26 \text {; } \\
\text { Coptic }\end{array}$ \\
\hline & & mid VIII & $\begin{array}{l}\text { KRU 73; Till, } 28 \text {; } \\
\text { Coptic }\end{array}$ \\
\hline & & $?$ & VC 120 ; Coptic \\
\hline & Syene & $?$ & $\begin{array}{l}\text { BM 447; cf. Crum, } \\
\text { RecTrav 22, } 223\end{array}$ \\
\hline & & $?$ & BM 448 ; cf. BM 447 \\
\hline & Panopolite & ? ed. IX-X & Hall $12,1(\# 662)\left({ }^{1}\right)$ \\
\hline & & VIII & P. Cair. Arab. III 167 \\
\hline & Hermopolite & VII, ind. 9 & $C P R$ IV 117 \\
\hline & Nubia & $\begin{array}{l}\text { ind. } 14(?), \text { Hathyr (?); } \\
\text { VIII }\end{array}$ & $\begin{array}{l}C P R \text { IV 28; Coptic } \\
\text { (partly lost) }\end{array}$ \\
\hline \multirow[t]{3}{*}{$2 L$} & Jeme (Thebes) & Date unknown & $\begin{array}{l}\text { KRU } 67 \text {; Till, } 27 \text {; in } \\
\text { Coptic: Tp]126 N80- }\end{array}$ \\
\hline & & $715 / 730(?)$ & $\begin{array}{l}\text { MOrCloC } \\
\text { KRU 9; Till, 18; in } \\
\text { Coptic: TETpIa[c] }\end{array}$ \\
\hline & & & $\begin{array}{l}\text { N80uoorcio arw } \\
\text { NPECTANBO }\end{array}$ \\
\hline \multirow[t]{3}{*}{$2 ?$} & Arsinoite & 762 & $S P P \times 169.10$ \\
\hline & Hermopolite & $\begin{array}{l}? \\
1 / 2 \text { VIII }\end{array}$ & $\begin{array}{l}\text { P. Lond. V } 1880 \\
\text { Ryl } 130 \text {; prov. uncer- } \\
\text { tain; } 2 \mathbf{J} / 2 \mathrm{G} \text { most } \\
\text { likely }\end{array}$ \\
\hline & Prov. unknown & $?$ & $\begin{array}{l}\text { ST } 340 \text { (only Father, } \\
\text { Son and Holy Ghost } \\
\text { preserved) }\end{array}$ \\
\hline
\end{tabular}

(1) Inscription; provenance unsure. 
4A Arsinoite

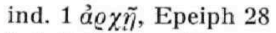

$B G U$ I 315

ind. 3, Pachon 17

$S B$ I 4816 (') $^{1}$

ind. $3 \tau \tau^{\prime} \lambda \varepsilon \iota$, Pauni 16

$B G U$ II 367

ind. 4, Mesore

$B G U$ II $366\left(^{2}\right)$

ind. 7 , Hathyr 7

$B G U$ III 737 (much

rest.; cf. $B L$ I 440 and

n. 2)

ind. 7, Pachon

$S B$ VIII 9775

ind. 7 $\varrho \chi \tilde{\eta}$, Epeiph 13

ind. 7 , Thoth 20

$S P P \times X 243\left(^{3}\right)$

ind. 9, Pauni 4

$B G U$ I $310\left({ }^{(4)}\right.$

$S B$ I $4483\left({ }^{5}\right)$; cf.

ind. 10

ind. 14 , Choiak

ind. 14 , Tybi 24

below, p. 131.

$B G U$ II 396

$B G U$ III 752

$S B$ I $4490\left({ }^{6}\right)$

$S B$ I 4737

$S B$ I 5319 (7)

$B G U$ I $320\left(^{(8)}\right.$

ind. 2, Mecheir 14

ind. 7 ả $\chi \tilde{\eta}$, Epeiph 27 ?

$S B$ I 4763

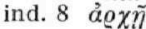

ind. 13

ind. 14, Mesore 28

$S B$ I 4870 (our rest.)

$S B$ I $4819\left({ }^{9}\right)$

$B G C$ III $750 \quad\left({ }^{10}\right)$

$S B$ I 4659

$S B$ I 4677

ind. 3

$S B$ I 5254 ( $\left.^{11}\right)$

$S B$ I 4672 (12)

$S B$ I 4694

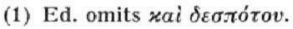

(2) Uses Saracene measure which points to a date after A.D. 641 ; cf. SPP XX 243 (infra, n. 3) for the scribe. Date: 645 or 660 ?

(3) Scribe also in P. Ross. Gearg. III 51 (631), SB VI 9461 (632), P. Lond. I 113 (6.b) (633) and SB I 4488 (635); cf. also BGU II 366 (supra, n. 2), SB: I 4490 (641 or 656 ? Cf. infra, n. 6) and 4672. Date: 648 or (less likely) 633?

(4) Ed. omits $\tau o \tilde{v}$ xv@lov.

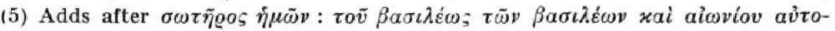
x@átogos. Cf. RFBE 82 for possible date in 621 .

(6) Ed. omits $\tilde{\eta} \mu \tilde{\omega} \nu$ жai $\tau \tilde{\eta} \zeta \delta \varepsilon \alpha \pi \circ i v \eta \xi$; cf. SPP XX 243 for scribe, supra, n. 3.

Date : 19.i. 641 , or (less likely) 20. i. 656.

(7) Omits MaQias in restoration.

(8) Cf. P. Ross. Georg. III 50.3n.

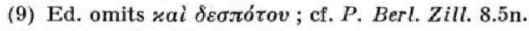

(10) Restore dํำ in line 3 ?

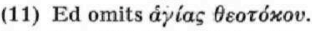

(12) Cf. $S P P \times X 243$ for the scribe, supra, n. 3. 


$\begin{array}{ll} & S B \text { I } 4703\left({ }^{1}\right) \\ \text { Epeiph 20 } & \text { SB I } 4762\left({ }^{2}\right) \\ \text { Pachon } & \text { SB I } 4767 \\ & S B \text { I } 4856 \text { (rest. ours) } \\ & S B \text { I } 4862 \text { (rest. ours) } \\ & S B \text { I } 4868 \text { (rest. ours) } \\ & \text { SPP XX } 258\left({ }^{3}\right) \\ & \left.\text { ZPE } 31(1978) 127 \quad{ }^{4}\right)\end{array}$

\section{FORMULA INCOMPLETE}

Arsinoite
P. Got. 96 (1 possible?)
$S B$ I 4742
$S B$ I 4778
$S B$ I 4805
$S B$ I $4832\left(^{5}\right)$
$S B$ I 4863
$S B$ I 4871 (1 possible)

The list above contains a considerable number of documents, obviously of the seventh or eigth century, in which we find an invocation but no regnal or consular date; generally only an indiction is given. There are three logical possibilities to explain these documents :

(a) They come from the period of Byzantine rule (after 591, of course) and leave the regnal date out by scribal error, haste, or laziness. Since the regnal formula was legally required on $\sigma v \mu \beta \dot{\lambda} \lambda \alpha \iota \alpha$ by Justinian in Novel 47 (A.D. 537), such an omission would be illegal : but not unparalleled, cf. SPP XX 209, P. Edfu I 2 and P. Lond. I 113 (6a). The difficulty lies in demonstrating that a document with only an indiction belongs in any particular cycle.

(b) They come from the period of Byzantine rule but were written during a period of political upheaval when scribes may have felt unsure who the ruler was. Borkowski has demonstrated that a series of documents with no regnal date but with the anomalous and antecedentless

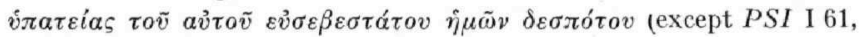
which has instead a regnal formula which omits the emperor's name)

(1) Ed. restores an extra ท́ $\mu \tilde{\omega}$.

(2) Ed. omits $\delta \varepsilon \sigma \pi a i v \eta \varsigma \hat{\eta} \mu \tilde{\omega} \nu \tau \tilde{\eta} \varsigma$.

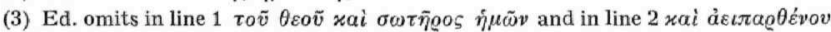
in his restorations.

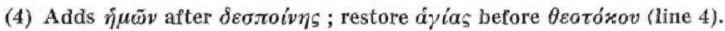

(5) Cf. P. Berl. Zill. 8.5n. 
in fact belong under Mauricius and Phocas. These are the following, all Oxyrhynchite except $S B 10798$ and $P$. Laur. 91, the provenance of which is unknown :

$\begin{array}{ll}\text { PSI III } 239 & \text { 9. ii. } 601 \\ \text { P. Oxy. XVI } 1991 & \text { 18. ix. } 601\left(^{1}\right) \\ \text { PSI III } 179 & \text { 25. xii. } 602 \text { ? See P. Laur. III 91. 1-7n. } \\ \text { P. Laur. III } 91 & \text { 30. xi. } 606 \\ \text { PSI I } 61 & \text { 8. v. } 609 \\ \text { SB XII } 10798 & \text { 10. vi. } 609 \text { (see BASP } 17 \text { [1980] 111) }\end{array}$

Borkowski $\left({ }^{2}\right)$ adds unpublished Oxyrhynchite texts of 598 and 602 .

(c) They can come from a period when there was no Byzantine government in Egypt. There are two such periods in question : 619-629, the Persian occupation of Egypt; and 641 and after, the Arab rule of Egypt. No regnal formula can be expected in these periods, and there is thus a natural temptation to date to these periods all texts lacking a regnal formula (except the group mentioned in section $b$ above).

We will take the documents with each invocation-type which lack a regnal date by group and ask whether some criteria for dating can be found.

\section{Formula 1 (Christ)}

There are 14 documents in this group, 1 from Hermopolis, 6 from Oxyrhynchos and 7 from the Arsinoite. With a simple Christ invocation, one expects a date either under Mauricius or under Heraclius. The total absence of Christ invocations in Lower Egypt under Phocas makes a date under that monarch unlikely. The indictions represented include $4,6,9,11,12$, and 13. Of these, no indiction 4 or 6 fell during the Persian rule of Egypt. Given that we have only one instance (P. Ross. Georg. III 56) of a Christ invocation securely datable after 641, and one undated instance (CPR IV 112d) which the editor assigned to the eight century, and given that the Christ formula normally found after 641 is the Christ. Mary and Saints formula (formulas $\mathbf{4 A}$ and $\mathbf{4 B}$ ) we apparently must admit that some of the undated examples of formula $\mathbf{1}$ are likely to fall into the reign of Mauricius or of Heraclius, thus 591-602, 610-619, or 629/630-

(1) See Borkowski (supra, p. 112, n. 1) n. 31.

(2) See Borkowski (supra, p. 112, n. 1) nn. 32-33. 
641. The documents are listed above (pp. 124-25). Cf. pp. 119 n. 2, 128, for the omission of regnal formula in SPP XX 209. It may be noted that our Oxyrhynchite datable documentation is very scanty after ca 620 .

\section{Formula 2 (Trinity)}

It was established above that various versions of formula 2 were in use in all of Egypt under Phocas, and that under Heraclius and then under Arab rule as long as Greek and Coptic invocations were written, the trinitarian formula persisted only in Upper Egypt. There is, however, one remarkable exception to this rule, viz. SPP X 169 . The provenance of this papyrus is the Arsinoite Nome, as the village names clearly show, and the date of the papyrus is A.D. 762, given the mentioning of a 15th indiction and the month Pachon, and given the name of the

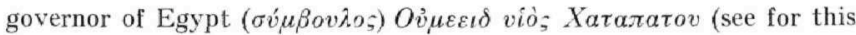
governor S. Lane Poole, A History of Egypt during the Middle Ages, London $\left.1925^{4}, 50\right)$.

Under the present conditions the task of assigning dates to the undated Upper Egyptian documents is formidable. Their indiction numbers include 1-4, 7-11, 13 and 14; of these 4 and 7 could not fall under Persian rule, and so once again we may exclude the hypothesis that all of them fell in the Persian period. We do have at least one document which seems to fall under Heraclius, but lacks a regnal year date, viz. P. Edfu I 2 (cf. supra, p. 120 n. 4). On the other hand, the Arab period cannot be excluded at all. It is worth observing that dated Greek documents from the Hermopolite Nome are very rare after the Persian period (i.e. from 630 onward), and that a date late in the 7 th century seems unlikely. But that is all we can say in this respect.

The variation of epithets of the Holy Trinity or the order of elements of the invocations is locally based, but similar in character to variations in

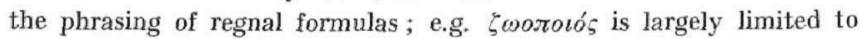
Upper Egypt.

\section{Formula 3 (Trinity, Mary and Saints)}

This formula is, within Egypt, limited to the Arsinoite Nome. There are no examples of this formula which are not datable to the reign of Phocas, except for $P$. Lond. I 113 (6.a) which dates from early Heraclius (cf. supra, p. 121). It is striking that the Arsinoite additions to the Upper Egyptian basic Trinity formula are the same as the Arsinoite additions to 
the Christ formula after 641 , except that two texts ( $B G U$ II 365 and ZPE 31 [1978] 130) omit the saints ; cf. formula 3A.

\section{Formula 4 (Christ, Mary and Saints)}

There is no example of this formula securely dated before 641 , and the burden of proof must be on anyone trying to show that one of these documents is of an earlier period. One could argue that the devotion to the cult of Mary and the saints is characteristic of Lower Egypt, particularly the Fayum, and burst out when not officially curtailed (cf. p. 119, n. 4). In this case the Persian period would also be possible. E. K. Chrysos (cf. p. 127, n. 5) has recently made a case for dating $S B$ I 4483 to the Persian period, A.D. 621 specifically. This text adds after

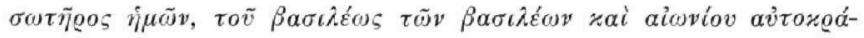
zogos, which is not found elsewhere $\left({ }^{1}\right)$. One might argue that while this justifies a dating to the Persian period, other documents cannot be so dated. But we do not think such an argument is conclusive.

It is thus evident that only to a limited degree can the invocations help pin down documents which do not have intrinsically useful dating criteria. We are certain that future prosopographical research may help to define ranges more closely. $\left({ }^{2}\right)$

APPENDIX : M. CHR. 290

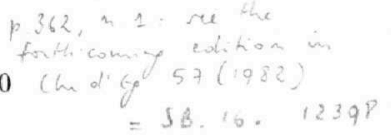

Carl Wessely published as CPR I 30 a Vienna papyrus numbered in the present inventory as G 19995 ; it was republished by L. MrtTeis in his Chrestomathie as no. 290. It consisted of two non-joining fragments containing a marriage contract of the sixth century coming from the

(1) This question raises problems we cannot deal with here. Cf. G. Röscr,

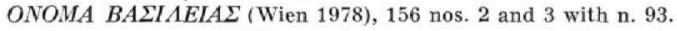

(2) C. H. RoBerts (Manuscript, Society and Belief in Early Christian Egypt,

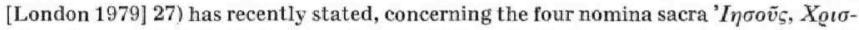

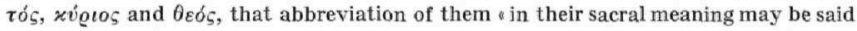
to be invariable." He goes on to remark, the contractions occur in documents as well as in literary manuscripts and where exceptions to the rule - rare even in documents - are listed they will be found on examination to occur in private letters or prayers or in e.g. magical texts, often the work of an amateur or careless scribe." These observations are not applicable to invocations, where the divine names are sometimes contrected, sometimes not, with no particular pattern observable. 
Fayum find. This contract, according to Wessely, began with the following invocation :

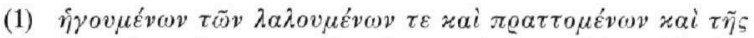

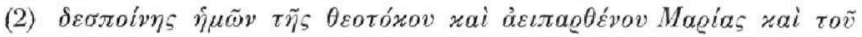

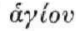

(3) ['I

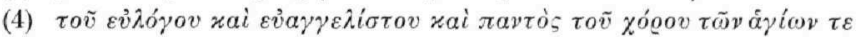

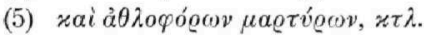

(4): Asohórov (WiLcken, BL I 117).

He did not restore a line before the first preserved one but in his translation rendered it " (Im Namen Gottes des Herrn) unserer Gedanken... " Mitteis, however, restored a first line of nearer the needed length, to wit :

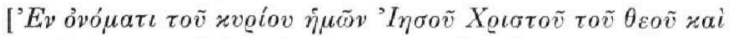

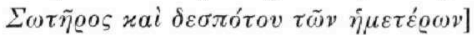

This restoration, however, is some 18-30 letters longer than the following lines; and in any case the entire formula is so long and elaborate as to be absolutely unparalleled. What is more, according to Wessely's edition the text proceeds immediately with the agreement and without any intervening regnal or consular formula, indiction, month, day, or place ; an extraordinarily unlikely situation and not to our knowledge paralleled in a sixth century document.

At our request, Dr. H. Harrauer has examined what is kept under this number and reported his findings to us. The following is a summary of the detailed information he has kindly provided (we have seen a photograph and can confirm the accuracy of these observations): (1) of fragment 1 there exists in the glass pane only part of line 2 (i.e. the first preserved one), $\dot{\gamma} \gamma o v \mu \varepsilon \dot{\varepsilon} \omega v \tau \tilde{\omega} v \lambda \alpha \lambda[$, and remnants of the start of line 3 : (2) these lines were not written by the same hand as the second fragment (the body of the contract) and the material also appears to be different; (3) the rest of what Wessely published as fragment 1 has not been found at all.

We are thus in the position of being unable to verify the readings of Wessely for fragment 1 ; nor can we be sure that that fragment has any connection at all with fragment 2 ; nor can we be certain if fragment 1 was really an invocation, rather than (let us say) an oath formula. Nor 
do we know how line 1 should be restored. The signatures reveal the provenance of fragment 2 to be Herakleopolis, but the groom comes from Justinianopolis, i.e. Cynopolis Parva, in the Delta (cf. E. Chrysos, Die Bisschofslisten des V. Oikumenischen Konzils [1966] 110).

Another possibility is that we do not have an invocation, but that it belongs to a liturgical context and is not connected with the invocation formulas found at the start of documents. Among preserved prayers on papyrus with some similarity to this text are P. Ness. III 89.45, P.Oxy. VIII $1151.40 \mathrm{ff}$., and $S B$ III $6087.15 \mathrm{ff}$. In this case the connection of the two fragments again remains uncertain.

We remain particularly perturbed by the absence of a dating formula of any sort, but we cannot offer any solution to the riddle of this papyrus.

A few places where the text of Wessely is incorrect may be noted here :

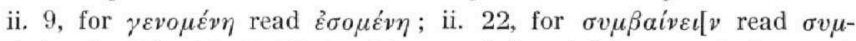

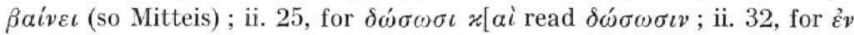

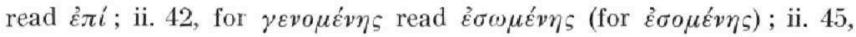
for $\gamma \alpha \ldots$ read $\tau \alpha[\beta(o v \lambda \alpha \varrho \iota o \zeta)$; ii. 51 , for second $\tau \tilde{\eta} \operatorname{read} \tau \tilde{\eta} \zeta$; ii. 52,

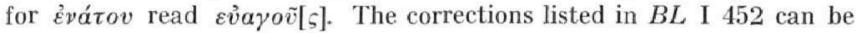
disregarded, as they are beyond the mark.

Columbia University

University of Amsterdam
Roger S. Bagnall

Klaas A. Worp 